\title{
Multinational Performance Relationships and Industry Context
}

\author{
Andersen, Torben Juul
}

Document Version

Final published version

Publication date:

2008

\section{License \\ CC BY-NC-ND}

Citation for published version (APA):

Andersen, T. J. (2008). Multinational Performance Relationships and Industry Context. Center for Strategic Management and Globalization. SMG Working Paper No. 15/2008

Link to publication in CBS Research Portal

\section{General rights}

Copyright and moral rights for the publications made accessible in the public portal are retained by the authors and/or other copyright owners and it is a condition of accessing publications that users recognise and abide by the legal requirements associated with these rights.

\section{Take down policy}

If you believe that this document breaches copyright please contact us (research.lib@cbs.dk) providing details, and we will remove access to the work immediately and investigate your claim. 
Multinational Performance Relationships and Industry Context Torben Juul Andersen

SMG WP 15/2008

April 14, 2008 
SMG Working Paper No. 15/2008

April 14, 2008

ISBN: 978-87-91815-28-7

Center for Strategic Management and Globalization Copenhagen Business School

Porcelænshaven 24

2000 Frederiksberg

Denmark

www.cbs.dk/smg 


\title{
Multinational Performance Relationships and Industry Context
}

\author{
Torben Juul Andersen \\ Copenhagen Business School \\ Center for Strategic Management \& Globalization \\ Porcelaenshaven 24B, 1.53 \\ DK-2000 Frederiksberg \\ Denmark \\ Phone: +45 3815-2514 \\ Email: ta.smg@cbs.dk
}

April 2008 


\title{
Multinational Performance and Industry Context
}

\begin{abstract}
Studies of multinational performance have moved from linear, to quadratic and to cubic relationships but despite this seeming increase in sophistication, the empirical evidence has remained contradictory. The hypothesized performance relationships of multinationality have typically been driven by assumed trade-offs between underlying cost/benefit functions. However, this paper argues that cost/benefit trade-offs associated with international expansion are shaped by industry specific conditions that systematically confound the performance outcomes of multinationality. Whereas prior studies often have been confined to a focus on manufacturing and smaller cross-sectional samples, this study analyses the multinational performance outcomes across a comprehensive industry-wide dataset during 1996-2000. The analyses show positive multinational performance relationships in manufacturing and knowledge-based service industries whereas capital-based service industries have negative performance relationships. These results support the proposed heterogeneity in multinational performance effects across industry contexts.
\end{abstract}




\section{Introduction}

The relationship between economic performance and multinational enterprise (MNE) continues to be subject to intense debate and existing results remain inconclusive. Some researchers found evidence of direct positive relationships between the level of multinationality and performance (e.g., Vernon, 1971; Grant, 1987; Grant/Jammine/Thomas, 1988) while others found neutral or even negative relationships (e.g., Buckley, 1977; Michel/Shaked, 1986). More recently there has been a focus on curvilinear relationships where analyses indicate an inverse u-shaped performance relationship (e.g., Daniels/Bracker, 1989; Ramaswamy, 1995; Gomes/Ramaswamy, 1999) while others found a ushaped relationship (e.g., Qian, 1997; Ruigrok/Wagner, 2003). A further extension of theses diverse outcomes has been to look for possible sigmoid relationships but yet again, the results seem to be conflicting (e.g., Contractor/Kundu/Hsu, 2003; Ruigrok/Wagner/Amann, 2004). As a consequence of the contradictory evidence, Hennart (2007) concludes that there is no strong theoretical support in the multinationality literature for positive performance outcomes.

It is argued that multinational performance derive from various sources ranging from economic effects of exploiting imperfections in factor and product markets (e.g., Buckley/Casson, 1976; Caves, 1971, Dunning, 1988) to managerial effects from wider deployment of corporate resources (e.g., Buhner, 1987; Kobrin, 1991; Talmann/Li, 1996; Teece, 1986) and operational flexibility (e.g., Kogut, 1985, 1989; Kogut/Kulatilaka, 1994). These rationales have been extended more recently to consider improved learning conditions in diverse environments accessible to MNEs (Bartlett/Ghoshal, 1998; Foss/Pedersen, 2002; Govindarajan/Gupta, 2001; Kogut/Zander, 1993). However, operating internationally is not frictionless. Managing a multinational structure catering to many different national conditions increases the level of complexity and uncertainty and thereby extends the cost of controlling and coordinating enterprise activities (e.g., Prahalad/Doz, 1987; Rosenzweig/Singh, 1991; Vernon, 1966; Zaheer/Musakowski, 1996). Given the countervailing forces of costs and benefits associated with multinational enterprise, the relative influences of these forces have been adopted as arguments for particular performance outcomes. This paper posits that the industry context can influence the cost/benefit trade-offs and thereby affect the performance relationships of multinationality. We adopt Stabell and Fjeldstad's (1998) chain, shop, and network 
configurations to assess the value and cost drivers applying to different industry contexts and analyze the associated effects on multinational performance.

The paper contributes to the ongoing debate about the performance effects of multinational enterprise. Many empirical studies are characterized by relatively small cross-sectional samples focused on a narrow range of industries. This limitation in data availability has rendered comparative analyses across industry contexts difficult and rare with Contractor/Kundu/Hsu (2003) constituting a notable exception. The paper addresses this shortcoming by assessing the cost/benefit trade-offs applying to different generic industry contexts and testing the hypothesized performance relationships of multinationality on a comprehensive cross-sectional dataset.

In the following, we first conduct a brief review of the literature discussing the benefits and costs of multinational enterprise (The Performance of Multinational Enterprise). Then we discuss how identified benefits and costs may apply to different industry contexts (The Role of Industry Context) and related hypotheses are developed from this discussion (Hypotheses). The hypotheses are tested on a cross-sectional sample of 1,175 US companies (Empirical Study). Finally, the results are discussed (Discussion) and conclusions drawn (Conclusion).

\section{The Performance of Multinational Enterprise}

\section{The Benefits Associated with Multinationality}

Many theoretical arguments have been forwarded to explain how multinationality can enhance performance. An organization with a global reach has the opportunity to exploit market imperfections that may exist between factor markets, product markets, and financial markets located in different national environments (Dunning, 1988; Teece, 1981). Hence, a multinational structure can facilitate better sourcing alternatives, provide a basis for international arbitrage through crossborder transactions, and give wider access to regional capital markets (e.g., Yip, 1995; Govindarajan/Gupta, 2001). It also allows the possibility of engaging in cross subsidization and price discrimination between national markets (Rugman, 1981). The ability to engage in factor cost arbitrage on a global scale provides opportunities to maximize location economies (Kogut, 1985, 
1989), gain operational flexibilities (Kogut, 1985; Kogut/Kulatilaka, 1994), and lever arbitrage opportunities (Annavarjula/Beldona, 2000; Daniels/Bracker, 1989). The expanded market reach may yield scale and scope economies (Buckley/Casson, 1976; Caves, 1971; Grant, 1987; Kobrin, 1991; Kogut, 1985; Porter, 1986; Tallman/Li, 1996) and allow the corporation to amortize investment over a larger market area (Bartlett/Ghoshal, 1998; Kobrin, 1991; Tallman/Li, 1996).

Business engagements across diverse markets may further lead to risk diversification and improved risk-return characteristics (Lessard, 1976). There may be wider access to perform effective scanning of global market and competitor developments (Grant, 1987; Vernon, 1966) with associated effectiveness in new product developments (Bartlett/Ghoshal, 1998). A multinational structure that controls access to knowledge-based resources in different national environments should be better at absorption and exchange of regional competencies (Cohen/Levinthal, 1990; Kogut/Zander, 1992). The firm can use its multinational reach to tap into local knowledge, absorb it, and transfer it to other entities and facilitate organizational learning (Kobrin, 1991; Teece, 1986). This may allow the firm to generate more and superior knowledge (Grant, 1996) and build unique insights across the multinational organization from access to local pockets of expertise (Kogut/Zander, 1993; Argote 1999). Hence, a multinational enterprise that transfers competencies and knowledge between overseas entities may enhance the development of global market opportunities (Andersen/Foss, 2005; Buhner, 1987; Lord/Ranft, 2000).

\section{The Costs Associated with Multinationality}

A major cost factor of multinational enterprise relates to the unfamiliarity with foreign ways of thinking and doing things (Hymer, 1976). Complex and dynamic international environments impose additional information processing needs on the organization and augment the associated communication costs (Egelhoff, 1988; Galbraith, 1977). For firms operating across many and diverse national environments, complexity is further augmented and imposes additional costs on the organization from dealing with the 'liability of foreignness' (Zaheer, 1996; Zaher/Musakowski, 1997). This may be reflected in increasing transaction costs (Jones/Hill, 1988) and agency costs (Roth/O’Donnell, 1996) associated with intra-firm activities. Complexity imposes higher control and coordination costs on the organization, which is further aggravated with increasing cultural diversity 
(Barkema/Bell/Pennings, 1996; Geringer/Beamish/daCosta, 1989; Gomes/Ramaswamy, 1999; Kogut/Singh, 1988). Thus, internationalizing firms are faced with incremental costs of acquiring knowledge about new unfamiliar market environments (Johanson /Vahlne, 1977, 1990) while the handling of differentiated customer needs may require additional coordination efforts (Prahalad/Doz, 1987; Bartlet/Ghoshal, 1998). At the same time, financial exposures may increase from extended cross border trade (Reeb/Kwok/Back, 1998) while overseas investments introduce new political risks (Boddewyn, 1988).

\section{The Cost/Benefit Dynamic in Multinational Enterprise}

As appears, we can reference a broad literature for many potential sources to multinational benefits. But, there are also distinct costs associated with multinational expansion that may offset, or more than offset, the benefits. Hence, the multinational enterprise is faced with important trade-offs between the benefits and costs of multinationality. The eventual performance relationship of the level of multinational activity arguably depends on the development of the underlying cost/benefit dynamic. A positive linear relationship of multinationality implies that the benefits of multinational activity increase at a higher rate than the associated cost at all stages of the internationalization

process (Grant, 1987; Grant/Jammine/Thomas, 1988). Conversely, a negative linear relationship assumes that costs associated with multinational expansion increase faster than the benefits of multinationality at all stages of the internationalization process (Figure $1 \mathrm{a} / \mathrm{b}$ ).

Insert Figure 1 about here

These relatively simple cost/benefit relationships may not prevail. It is argued that early internationalizers have low initial costs of acquiring foreign market information when they start expansion into countries that are geographically and culturally close to the home environment (Davidson, 1980, 1983; Johanson/Vahlne, 1977; Papadopoulos/Denis, 1988). However, at later stages of the international expansion, engagement in increasingly unfamiliar cultural environments 
could increase costs exponentially (Vernon, 1966; Geringer/Beamish/daCosta, 1989). Under those circumstances, multinational expansion will occur rather smoothly up to a certain point beyond which the costs may increase at a faster rate than the benefits (Al-Obaidan/Scully, 1995; Gomez/Ramaswamy, 1999; Katrishen/Scordis, 1998; Mishra/Gobeli, 1998). At the same time, the benefits of multinationality may level off and display a diminishing marginal value contribution at higher levels of international expansion (Hitt/Hoskisson/Kim, 1997; Siddharthan/Lall, 1982). As a consequence, high levels of multinationality would be associated with decreasing profitability (Daniels/Bracker, 1989; Geringer/Beamish/daCosta, 1989; Gomes/Ramaswamy, 1999; Ramaswamy, 1995) causing the performance relationship of multinationality to display an inverted j-curve (or inverse u-curve) relationship (Figure 2a). This reasoning has supported the notion of an 'internationalization threshold' with a general prediction that multinational expansion beyond a certain level is unprofitable (Ramaswamy, 1995; Sullivan, 1994) although the phenomenon possibly could be industry specific (Gomez/Ramaswamy, 1999).

Accepting the argument that early internationalizers face relatively low initial costs (Johanson/Vahlne, 1977; Papadopoulos/Denis, 1988), it could also be reasoned that while continued international expansion imposes increasing costs, it will take place at diminishing increments because the organization moves along an experience curve where initial improvements in the handling of multinational diversity are the highest (Hitt/Hoskisson/Kim,1997; Johanson/Vahlne, 1990; Ruigrok/Wagner, 2003). At the same time, access to diverse international resources can facilitate the use of regional competencies and knowledge to exploit global market opportunities, which may grow exponentially as the international reach is extended (e.g., Buhner, 1987; Dunning, 1998; Kobrin, 1991; Kogut/Zander, 1993). Together, these assumptions lead to a u-shaped performance relationship of multinationality (Figure 2b). Ruigrok/Wagner (2003) found that this indeed seem to be the case for German companies. They partly ascribe this phenomenon to higher cost of initial international expansion for German compared to US companies, which can explain the inverse findings in these two national market environments.

Insert Figure 2 about here 
However, Sullivan (1994) suggested a focus on convergence cycles with more than one inflection point along the multinational expansion path. Hence, it may be argued that early internationalizers are faced with rapidly increasing costs due to the prevalence of 'liabilities of foreignness' (Contractor/Kundu/Hsu, 2003; Gongming, 1998; Zaheer, 1995; Zaheer/Musakowski, 1997) although this trend will level off as the organization learns how to handle the multinational diversity (Johanson/Vahlne, 1990; Ruigrok/Wagner, 2003). However, as further international expansion proceeds into increasingly unfamiliar cultural environments, costs may start to increase exponentially (Geringer/Beamish/daCosta, 1989; Gomes/Ramaswamy, 1999) and high complexity may eventually lead to loss of strategic control (Prahalad/Doz, 1987; Hitt/Hoskisson/Kim, 1997). Since it may take time to learn how to exploit the advantages from the multinational presence, benefits could initially accrue at a low rate whereas advantages derived from scale and scope economies (Buckley/Casson, 1976; Grant, 1987; Kobrin, 1991; Kogut, 1985), international arbitrage (Annavarjula/Beldona, 2000; Daniels/Bracker, 1989; Yip, 1995; Govindarajan/Gupta, 2001), cross subsidization (Rugman, 1981), and location economies (Kogut, 1985, 1989) might accrue only after a certain level of international expansion has been reached. At very high levels of multinational activity, the benefits may again level off as expansion continues into increasingly marginal market areas (Contractor/Kundu/Hsu, 2003; Siddharthan/Lall, 1982). Under these assumptions, the performance relationship of multinationality will follow an s-curved shape (Figure 3a) as supported by some recent empirical studies (Contractor/Kundu/Hsu, 2003; Lu/Beamish, 2004).

Under other circumstances, it could be argued that early internationalizers face low incremental costs (Johanson/Vahlne, 1977, 1990) but later will incur rapidly increasing costs due to widespread activities across diverse foreign environments (Al-Obaidan/Scully, 1995; Geringer/Beamish/daCosta, 1989; Gomez/Ramaswamy, 1999; Zaheer, 1995). A higher level of complexity and increasing communication and coordination costs derived from continued internationalization may eventually require an organizational restructuring to reconfiguration internal processes and systems so they can integrate the diversity of multinational activities (Bartlett/Ghoshal, 1998; Egelhoff, 1988; Hitt/Huskisson/Kim, 1997; Prahalad/Doz, 1987; Sullivan, 1994). Once the reorganization has been accomplished, the firm might again be able to continue 
multinational expansion and reap the benefits from scale and scope economies (Buckley/Casson, 1976; Grant, 1987; Porter, 1986; Tallman/Li, 1997), cross-border arbitrage (Dunning, 1988; Daniels/Bracker, 1989; Teece, 1981), operational flexibilities (Kogut, 1985; Kogut/Kulatilaka, 1994), etc., without incurring incremental costs. This reasoning would lead to a performance relationship of multinational expansion that follows an inverse s-curve (Figure 3b). Empirically studies have found evidence of such a performance relationship among Swiss multinationals (Ruigrok/Wagner/Amann, 2004).

Insert Figure 3 about here

As appears from this discussion, various performance relationships of multinationality can be derived based on different rationales about the underlying cost/benefit trade-offs and may reach rather different outcomes as discussed in the extant literature. The potential contradictions associated with this discussion are enforced by empirical studies that seem to provide support for all the proposed performance relationships. While there has been some adherence to a deterministic view in terms of a 'multinationality threshold' (Ramaswamy, 1995; Geringer/Beamish/daCosta, 1989; Gomez/Ramaswamy, 1999) and a universal s-curve relationship (Contractor/Kundu/Hsu, 2003; Lu/Beamish, 2004; Riahi-Belkaoui, 1998) other researchers have pointed to potential causes for divergence. These include possible effects from diverse home country environments (Ruigrok/Wagner, 2003; Ruigrok/Wagner/Amann, 2004), the time periods being analyzed (Daniels/Bracker, 1989; Grant, 1987; Geringer/Tallman/Olsen, 2000), and firm specific managerial competences, such as, innovation and marketing (Kotabe/Srinivasan/Aulakh, 2002), integrative strategy processes (Andersen, 2004), and communication technologies (Andersen/Foss, 2005).

Hence, the literature is replete with suitable arguments to explain why the multinational performance function might take the shape of linear, curvilinear, or sigmoid relationships where empirical studies find traces of them all. However, there has been little consideration of the cost/benefit dynamics of specific industry contexts and how they might affect multinational performance outcomes in ways that could partially explain the seemingly contradictory empirical results. Hence, the following 
section will focus on how different generic industry contexts may influence the way in which multinational enterprises operate.

\section{The Role of Industry Context}

\section{Differential Cost-Benefit Effects}

Prior empirical analyses on the performance relationship of multinationality have predominantly been based on companies operating in manufacturing industries. In view of the increasing importance of services in the global economy, however, Contractor, Kundu and Hsu (2003) assumed an extended industry perspective in an initial study of multinational performance relationships across service industries. Their analysis assumed a rather broad classification of two supposedly distinct service sectors comprising knowledge-based and capital-based services. This provided important insights to the multinational performance relationships for different types of services. However, there may be a need to adopt a more theoretically systematic classification of industry contexts to gauge the under underlying cost/benefit dynamics in more comprehensive studies.

Many advantages associated with multinational expansion seem applicable across industries and may constitute rather universal arguments for internationalization efforts. A wider global reach across national markets should put any firm in a better position to source inputs and distribute outputs thereby providing an ability to exploit imperfections in factor and product markets through arbitrage and internal resource deployment (Annavarjula/Beldona, 2000; Daniels/Bracker, 1989; Dunning, 1988). To the extent products and services cater to constituents in multiple market environments there should also be room for scale and scope economic benefits (Buckley/Casson, 1976; Grant, 1987; Kobrin, 1991; Tallman/Li, 1996). The ability to scan global competitive conditions and using this to improve customer offerings and internal processes appear equally relevant across industries (Bartlett/Ghoshal, 1998; Buhner, 1987; Grant, 1987). On the cost side, all organizations will be exposed to unfamiliar environments when they internationalize and will incur costs to learn the foreign ways (Hymer, 1976; Johanson /Vahlne, 1977, 1990; Zaheer, 1995). Diversity and complexity is also bound to increase thereby inflicting additional information 
processing, communication, and coordination costs on any multinational organization (Bartlet/Ghoshal, 1998; Egelhoff, 1988; Galbraith, 1977; Prahalad/Doz, 1987). Nonetheless, despite these seemingly general effects of multinationality there are likely to be subtle differences in the underlying cost/benefit dynamics across industry contexts.

\section{Manufacturing Industries}

Multinational enterprise in manufacturing industries should be prone to exploit location economies (Kogut, 1985, 1989). That is, companies that depend on sourcing of tangible input factors, including raw materials and labor, should be in a better position to establish manufacturing facilities and logistics systems in a way that gives access to cost efficient factor inputs of sufficient quality (Annavarjula/Beldona, 2000; Daniels/Bracker, 1989). This also entails potential operational flexibilities that could allow switching of production across different economic regions (Kogut, 1985; Kogut/Kulatilaka, 1994) with potential positive risk management effects (Lessard, 1976). Manufacturing firms are characterized by turning physical inputs into enhanced physical outputs and comprise a wide range of products from household goods like food, clothing and furniture to hightech products like machinery, computers and electronics. Manufacturing represents a long-linked sequential technology with sequential value creating activities that can be analyzed as a conventional value chain (Stabell/Fjedstad, 1998). In this industry context, competitive advantage relates to economic efficiencies along the value chain with scale, capacity utilization and scope economies as the major drivers of cost advantages. Hence, a major challenge in multinational manufacturing is to create appropriate 'fit' between functional elements in the multinational value chain and gain economic efficiencies by scaling operations and sharing activities across national product markets (Porter, 1986, 1996). The ability to pursue this can be enhanced by communication and information technologies for process integration across geographically dispersed business entities and monitoring of economic exposures (Andersen/Foss, 2005).

\section{Trading Industries}

A significant number of firms operate in trading industries including businesses like wholesalers, 
department stores, supermarkets and other retailers. Trading businesses do not produce but channel goods between producers and consumers that can be analyzed as a value chain configuration like manufacturing firms. Therefore, comparative advantages are gained from the scale and scope economies of different value activities. Trading firms are in a good position to scale their distribution assets to fulfill immediate market needs as well as extended international expansion. A lower fixed cost element reduces pressures to gain scale economies and increase flexibilities in foreign market entry. Hence, trading firms have little pressure to expend large capital outlays across extensive geographies but may pick the most suitable foreign markets in their internationalization strategy. Extending a trading business across essential national markets should provide good arbitrage opportunities (Daniels/Bracker, 1989; Annavarjula/Beldona, 2000) as well as price discrimination and cross-subsidization between different regions (Rugman, 1981). Similarly, a prudent choice of market locations can offer opportunities for operational flexibilities in global sourcing and logistics systems (Kogut, 1985; Kogut/Kulatilaka, 1994). The use of communication and information technologies can enhance efficiencies of the global sourcing, inventory, distribution, and invoicing systems adopted by trading firms (Andersen/Foss, 2005).

\section{Service Industries I}

Turning to services researchers have identified companies operating in knowledge-based service industries (Contactor/Kundu/Hsu, 2003) comprising professional service companies in businesses like medicine, law, architecture, engineering, oil exploration, consulting, etc. These organizational structures have been referred to as value shops as distinct from value chains (Stabell/Fjedstad, 1998). These firms manage knowledge workers with a technology geared to solve customer problems. The operational requirements relate to client origination, problem analysis, execution of solutions and control processes to ensure output quality. The operational processes are iterative, interactive, and cyclical with labor intensive value activities that lever unique expertise. The cost drivers of value shops are not significant but value is contributed by market reputation that may convince potential clients about the reliability of proposed solutions. The multinational expansion of these kinds of organizations should be prone to learning from the exchange of regional expertise accessible across the multinational organization (Daniels/Bracker, 1989; Grant, 1996; Kogut/Zander, 1992, 1993) 
where diverse knowledge sources can support the development of innovative opportunities (Desouza/Evaristo, 2003; Foss/Pedersen, 2002; Mudambi, 2003). Like in manufacturing, use of communication and information technologies may facilitate the integration of diverse knowledge across multinational business entities (Andersen/Foss, 2005).

\section{Service Industries II}

Other types of services have been identified as capital-based (Contactor/Kundu/Hsu, 2003). Firms operating in capital-based service industries comprise telecommunication, cable networks, television stations, internet service providers, transportation and logistics companies, airlines, etc. They constitute organizational structures referred to as value networks as distinct from value chains and value shops (Stabell/Fjedstad, 1998). These firms use mediating technologies to link customers in exchange of goods, people, information, etc. The operational requirements of these firms include ongoing infrastructure maintenance, network promotion, and servicing of linked customers. Value creation arises from positive network externalities and related capacity opportunities. Cost advantages are similarly driven by scale economies and capacity utilization. These companies need to engage in substantial fixed asset investment to establish business networks of sufficient size and enable servicing of a large international customer base. Hence, it is advantageous to establish an extensive economic infrastructure from the outset to gain the benefits from positive network externalities and amortize the up-front investment over a larger global market (Bartlett/Ghoshal, 1998; Kobrin, 1991; Tallman/Li, 1996). All the while, the potential for new product development opportunities may be limited because success primarily depends on international promotion of the supportive infrastructure (Bartlett/Ghoshal, 1998; Buhner, 1987). These conditions may have adverse implications for the companies' risk-return profiles and expose them excessively to financial and political risks (Boddewyn, 1988; Lessard, 1976; Reeb/Kwok/Back, 1998). The need for an extended global reach to gain positive network externalities and scale economies may force these companies to expand into increasingly unfamiliar overseas environments that may impose additional knowledge acquisition cost and complexities on the organization (Hymer, 1976; Johanson /Vahlne, 1977, 1990; Zaheer/Musakowski, 1997). 


\section{Hypotheses}

Based on the theoretical discussions above we proceed to formulate associated hypotheses. MNEs in manufacturing industries appear to mainly have advantages associated with an extended international organization in the form of location economies (Kogut, 1985, 1989), factor market arbitrage (Annavarjula/Beldona, 2000; Daniels/Bracker, 1989), and operational flexibilities (Kogut, 1985; Kogut/Kulatilaka, 1994). Trading firms should be able to gain from arbitrage opportunities between national market entities (Rugman, 1981; Daniels/Bracker, 1989; Annavarjula/Beldona, 2000) while retaining sufficient investment and operational flexibilities (Kogut, 1985; Kogut/Kulatilaka, 1994). The coordination costs in these industry contexts may be handled very effectively through means of information and communication technologies (Andersen/Foss, 2005; Porter, 1996). Since these firms can manage their variable/fixed cost ratios, they are relatively flexible in the choice of multinational expansion and, therefore, should display little change in cost/benefit dynamic as the degree of multinationality expands. Hence, we ascertain that manufacturing and trading companies alike are likely to take advantage of a multinational structure.

Hypothesis 1: Companies operating in manufacturing and trading industries will generally display a positive relationship between multinationality and performance.

MNEs in knowledge-based service industries predominantly face incremental advantages from an extended international organization by way of learning through knowledge exchange (Grant, 1996; Kogut/Zander, 1992, 1993; Lord/Ranft, 2000) and associated development of new opportunities (Desouza/Evaristo, 2003; Foss/Pedersen, 2002; Mudambi, 2003). International expansion does not require extensive investment in an economic infrastructure of fixed assets but is associated with the relatively low-cost transfer of knowledge-based assets, i.e., the value shop structure imposes few operational frictions (Stabell/Fjedstad, 1998). Hence, these firms should have very high flexibility in their choice of multinational presence with limited changes in their cost/benefit dynamics of multinational expansion. Hence, we suggest that knowledge-based service companies most likely will be advantaged by a multinational structure. 
Hypothesis 2: Companies operating in knowledge-based service industries will generally display a positive relationship between multinationality and performance.

Capital-based service businesses depend on investment in large supportive distribution networks to gain from positive network externalities and scale economic efficiencies. The high fixed/variable cost ratio associated investment in extensive global infrastructure assets may cause costs to exceed the potential benefits from international expansion over long periods of time. Furthermore, MNEs in capital-based service industries are exposed to downside performance effects as the dependence on infrastructure investments reduce flexibilities and limit new product opportunities (Bartlett/Ghoshal, 1998; Buhner, 1987). Finally, the pressures for global expansion may overextend exposures to operational, financial, and political risks (Boddewyn, 1988; Lessard, 1976; Reeb/Kwok/Back, 1998). Hence, we foresee that capital-based service companies may face economic disadvantages at least in the initial phases of their multinational market expansion.

Hypothesis 3: Companies operating in capital-based service industries may display a negative relationship between multinationality and performance that turn into a positive relationship for high levels of multinationality.

In the subsequent section we outline and describe an empirical study devised to test the hypotheses.

\section{Empirical Study}

\section{Data}

Organizations were sampled from the Compustat database comprising the 1000 largest firms by total turnover, the 1000 largest firms registered by Dun \& Bradstreet, and the Fortune 500 companies. Only firms with complete datasets for the entire period from 1996 to 2000 were included. Due to an overlap in the selection criteria, the final sample consisted of 1,175 firms operating across industries 
identified by four-digit SIC codes in Compustat. Hence, all the performance measures and control variables included in the study were derived from archival data available in Compustat.

\section{Measures}

As measures of multinational performance, we used return on assets (ROA), calculated as earnings before interest and taxes (EBIT) divided by total assets, and return on investment (ROI), determined as earnings before interest and taxes (EBIT) divided by capital employed, i.e., the sum of outstanding debt and retained earnings. The two performance indicators provide slight nuances with ROA possibly being more dependent on accounting practices connected to asset valuations. While ROI may constitute a more exact measure of economic return, the use of ROA as performance indicator is consistently used in previous studies (e.g., Contractor/Kundu/Hsu, 2003; Daniels/Bracker, 1989; Gomes/Ramaswamy, 1999; Hitt/Hoskission/Kim, 1997; Ruigrok/Wagner, 2003).

Multinationality was measured on the basis of the number of countries in which the company has foreign subsidiaries (Kogut/Singh, 1988). Other researchers have suggested multiple indicators to measure degree of multinationality (e.g., Annavarjula/Beldona, 2000; Sullivan, 1994). However, Gomes/Ramaswamy (1996) found the number of foreign countries correlated with foreign sales/total sales (FSTS) and foreign assets/total assets (FATA) and loading on the same component in factor analysis. The number of foreign countries with subsidiaries captures the essential elements of the cost/benefit dynamics associated with the level of multinationality as the number of countries served by the MNE reflects the organizations appropriability regimes (Teece, 1986). An alterative measure was also adopted to capture both the number of subsidiaries and the number of countries as a better proxy for costs and benefits associated with diversity but did not lead to material changes in the results. The multinationality measure was calculated as the sum of the natural logarithm of one plus the number of foreign countries in which the firm has a presence. The natural logarithm was applied to adjust for data skewness. The information on foreign subsidiaries was obtained from America's Corporate Families and International Affiliates, III, Dun \& Bradstreet (2001). 
The study considered a number of control variables to ensure that multinationality as the independent variable is a prime explanatory source and not the result of undisclosed mediating factors. Previous studies have typically used organizational size as a potential performance influencer (e.g., Gomes/Ramaswamy, 1999; Kotabe/Srinivasan/Aulakh, 2002; Ruigrok/Wagner, 2003) and have adopted dummies to control for industry effects where applicable (e.g., Contractor/Kundu/Hsu, 2003; Gomes/Ramaswamy, 1999; Ruigrok/Wagner, 2003). Hence, the natural logarithm of total assets was included as control variable to remedy the positive skew in data size, and dummy variables for major industry sectors identified around two-digit industry codes were included as well.

A recent study found that innovation strategy can affect multinational profitability (Kotabe/Srinivasan/Aulakh, 2002) and, therefore, R\&D intensity (measured as R\&D expenditures divided by total assets) was included as control variable. The company's funding structure may affect the performance measures (Hitt/Hoskisson/Kim, 1997) and, therefore, financial leverage (measured as total debt divided by retained earnings) was included as a control variable. The market evaluation of firm assets compared to the accounting values on the books may affect the performance measures (Fama/French, 1992) and, therefore, the market-to-book ratio (measured as the market value of the firm divided by retained earnings) was included as a control variable.

Two other control variables were considered namely the level of environmental dynamism (measured as the standard deviation of the regression coefficient on the five-year trend line of total sales in the industry divided by total sales) as a potential influencer of industry profitability (Simerli/Li, 2000), and diversity (measured as the logarithm of one plus the number of four-digit industries in which the company operates) as an influencer of the multinationality performance relationship (Hitt/Hoskisson/Kim, 1997). However, these two variables were not statistical significant and did not materially affect relationship coefficients and were, therefore, excluded from the reported results (Kleinbaum/Kupper/Muller/Nizam, 1998). All performance indicators and control variables were measured as average values over the five-year period 1996-2000 to avoid potential spurious effects and noise caused by periodic accounting adjustments, etc. Table 1 provides 
descriptive statistics of the total sample.

Insert Table 1 about here

\section{Methodology}

The hypotheses were tested through use of multiple regression analyses, which has been the most commonly adopted approach in comparable studies (e.g., Hitt/Hoskisson/Kim, 1997; RiahiBelkaoui, 1998; Ruigrok/Wagner, 2003). Some studies have used a pooled time series regression technique often to overcome relatively small sample sizes and thereby gain in statistical power (e.g., Contractor/Kundu/Hsu, 2003; Gomes/Ramaswamy, 1999; Kotabe/Srinivasan/Aulakh, 2002). However, a potential downside to this technique is that it can capture autoregressive time relationships that reflect underlying trends in the smaller industry-specific sample (Contractor/Kundu/Hsu, 2003; Hill/Phan, 1991). Since, one of the strengths of the present study is the comprehensive sample across multiple industries, classical regression was chosen as the appropriate methodology. The statistical significance of regression coefficients with ROA and ROI as dependent variables and multinationality to the first, second, and third power analyzed potential linear, quadratic, and cubic performance relationships in the total cross sectional sample. Comparable multiple regressions on industry sub-samples comprising companies operating in manufacturing, trading, knowledge-based and capital-based service industries tested hypotheses 1, 2, and 3. All independent variables in the regressions were tested for multi-collinearity and the error terms in the multiple regressions were checked for outliers, heteroscedasticity, and normality (Kleinbaum/Kupper/Muller/Nizam, 1998).

\section{Results}

The first regression analyses indicate that multinationality has a significant direct relationship to both performance indicators (Table 2). The regression coefficient of the quadratic multinationality measure against ROI is positive and statistically significant, while none of the other coefficients show statistical significance. Hence, the study indicates a linear, and possibly slightly exponential, 
positive relationship between multinationality and performance across industries. The second regression analysis performed on a sub-sample of manufacturing companies finds a significant direct positive relationship between multinationality and both performance indicators in this industry context (Table 3). This provides support for hypothesis 1 . The third regression analysis performed on a sub-sample of trading companies did not discern linear or u-shaped performance relationships but the last regression run using ROA as dependent variable indicates a statistically significant inverse s-curve relationship (Table 4). This provides partial support for hypothesis 1 . The fourth regression analysis performed on a sub-sample of knowledge-based service companies confirms that multinationality has a significant direct relationship to both performance indicators in this industry context (Table 5). This provides support for hypothesis 2.The fifth regression analysis performed on a sub-sample of capital-based service companies finds significant direct negative relationships to both performance indicators, while there is no significant indication of quadratic or cubic performance relationships in this industry context (Table 6). This provides general support for hypothesis 3.

Insert Table 2 about here

Insert Table 3 about here

Insert Table 4 about here

Insert Table 5 about here

Insert Table 6 about here

\section{Discussion}

\section{Main Findings}

The empirical findings from the analysis of the cross-sectional sample reported in this study paint a 
rather positive picture of the performance outcomes deriving from multinational expansion. However, this overarching result covers for nuances observed across the underlying industry contexts. The regression results on the full cross-sectional sample indicate a significant positive direct relationship between multinationality and performance. The manufacturing sub-sample comprises a range of products including household goods, pharmaceuticals, petroleum, machinery, computers, semiconductors, etc. The regression analyses performed on this sub-sample repeated the positive direct performance relationship thus confirming that net benefits may accrue from multinational expansion in these industries, e.g., due to location economies, factor cost arbitrage, and operational flexibilities (Annavarjula/Beldona, 2000; Daniels/Bracker, 1989; Kogut, 1985; Kogut/Kulatilaka, 1994).

The trading sub-sample including wholesalers and distributors of various products and retailing outfits like department and grocery stores, gas stations, and various outlets for clothing, furniture, radios, electronics, etc., show a significant positive performance relationship to multinationality. However, it also reveals the contours of a potential sigmoid relationship although statistically insignificant. As the only industry context, the analyses identify an inverse s-shaped relationship, which may reflect that companies in these industries are less dependent on the recovery of large infrastructure investments and, therefore, have more flexibility in their choice of multinational expansion. By choosing a presence in key markets, these firms may take advantage of arbitrage opportunities, price discrimination, and cross subsidization between national markets (Annavarjula/Beldona, 2000; Daniels/Bracker, 1989; Rugman, 1981). But, if they expand further into peripheral markets, there may be a need to restructure and establish a more efficient sourcing and distribution channels to reap the potential benefits of the operational flexibilities (Kogut, 1985; Kogut/Kulatilaka, 1994).

The knowledge-based service sub-sample including advertising, accounting, education, engineering, consulting, hospitals, laboratories, programming, and software development provide similar evidence of a positive direct performance relationship of multinationality. That is, a knowledgebased service industry context seems to allow exploitation of multinational advantages deriving from organizational learning processes exchanging regional knowledge sources (Daniels/Bracker, 1989; Foss/Pedersen, 2002; Grant, 1996; Kogut/Zander, 1992, 1993; Mudambi, 2003). Hence, the 
industrial settings of manufacturing, trading, and knowledge-based service businesses all display positive performance relationships to multinational expansion.

However, the capital-based service companies including railroads, trucking, air transportation, cargo freight, telecommunication, broadcasting, cable, electric, and transmission services show a direct negative performance relationship to multinationality. This seems to confirm the potential downsides associated with extensive capital requirements that are peculiar to this industry context (Contactor/Kundu/Hsu, 2003). To amortize fixed investment cost over a larger global market (Bartlett/Ghoshal, 1998; Kobrin, 1991; Tallman/Li, 1996) these firms may be forced to expand internationally and thereby increase financial and political exposures (Boddewyn, 1988; Reeb/Kwok/Back, 1998). As a consequence the firms may not recover the initial investment costs over extended periods of time.

If we gauge the signs of the regression coefficients across the analyses of the industry sub-samples, it is observed that the coefficients of the linear, quadratic, and cubic expressions of multinationality indicate the weak (but not statistically significant) contours of an inverse s-shaped performance relationship in most industries. That is, the regression analyses on the full sample, the manufacturing, the trading, and the capital-based service companies all display positive, negative, and positive coefficient signs respectively. Conversely, the regression analysis performed on the knowledge-based service companies show negative, positive, and negative coefficient signs, i.e., they indicate the contours of an s-shaped performance relationship. Incidentally, these weak (but not statistically significant) performance relationships are consistent with the results reported by Contractor/Kundu/Hsu (2003) where capital-based service firms displayed and inverse s-curve relationship and the knowledge-based service firms an s-curve relationship. Hence, it is tempting to consider whether application of pooled time series regression techniques can lead to statistically significant results (e.g., Contractor/Kundu/Hsu, 2003; Ruigrok/Wagner, 2003). However, analyzing the performance relationship on a pooled time series did not find statistical significance in the indicated sigmoid curvature. The extended analysis reproduced the linear relationships and further specified these as immediate or delayed u-curve relationships with different 'tilts' in all industries except trading, where the inverse s-shaped performance relationship was repeated. In other words, 
compared to previous studies that support the concept of an international expansion threshold (Daniels/Bracker, 1989; Geringer/Beamish/daCosta, 1989; Gomes/Ramaswamy, 1999; Ramaswamy, 1995; Sullivan, 1994) that phenomenon has not been confirmed in this study, which is based on a more comprehensive and recent dataset. Similarly, there is no indication of a sub-optimal stage 3 in the knowledge-based service industries (Contractor/Kundu/Hsu, 2003).

\section{Limitations and Perspectives}

The sampling of companies among the largest US companies could reduce the relevance of the collected data because large organizations may be further along in the internationalization process than smaller firms. However, the US economy constitutes a large home market that can satisfy the growth potential of large firms and the collected date do indeed indicate a large deviation in the level of multinationality across the sampled firms. Hence, the focus on large US firms could be seen as an advantage to this type of study because many of them would be seriously considering home market versus multinational expansion as realistic strategic choices.

With a singular focus on US based companies, this study cannot provide comparative analysis on the effects of home country origin although it provides a good comparative contrast to the previous studies based on US firms. Hence, it is interesting to note that this study finds positive linear and possibly u-curve performance relationships among US manufacturing firms, which is at odds with several US-based studies finding inverse u-curve relationships (Daniels/Bracker, 1989; Gomes/Ramaswamy, 1999; Sullivan, 1994) but corresponds to results obtained in analyses of German manufacturing firms (Ruigrok/Wagner, 2003). An explanation for these contradictory results could be found in the influence of time as performance relationships are likely to change over time (Hitt/Hoskisson/Kim, 1997; Geringer/Tallman/Olsen, 2000). Three studies that found inverse ucurve relationships were based on data series covering a period from the 1970es to 1995 (Daniels/Bracker, 1989; Gomes/Ramaswamy, 1999; Sullivan, 1994) whereas Ruigrok/Wagner (2003) based their study on data from 1993-1997, that is, a period partially coinciding with the more recent data series used in this study. One reason why the performance relationship of multinationality improves over time could be the emergence of new communication and information technologies that allow manufacturing firms to integrate processes more efficiently across global 
entities than has been the case in earlier periods (Andersen/Foss, 2005).

Finally, the multinationality measure is not able to distinguish between the types of foreign subsidiaries the MNEs have established. However, it could be useful to differentiate, e.g, between production and sales entities, which might show that wide international dispersion of production plants is a disadvantage to manufacturing firms whereas sales offices possibly could be more widely distributed without incurring large incremental cost and loss of operational efficiency. However, future studies will have to consider these effects.

\section{Conclusions}

The performance of multinational expansion is influenced by developments in the underlying cost/benefit trade-offs. Particular industrial conditions can display different cost/benefit dynamics that may lead to diverse performance effects across industries. These industry specific cost/benefits dynamics may change over time, e.g., as use of information and communication technologies improve the ability to coordinate activities in complex dispersed multinational structures. The results from an empirical analysis of a comprehensive cross-sectional sample of US based companies indicate largely positive performance relationships to multinational expansion during the period 1996-2000 with some nuances observed between industries. Companies operating in manufacturing, trading, and knowledge-based service industries show positive performance relationships whereas firms in capital-based service industries show negative performance relationships. Hence, the empirical evidence provides strong support for the proposition that the performance effects of multinational expansion is confounded by industry-specific conditions. 


\section{References}

Al-Obaidan, A./Scully, G., The Theory and Measurement of the Net Benefits of Multinationality: The Case of the International Petroleum Industry, Applied Economics, 27, 1995, pp. 231-238.

Andersen, O., On the Internationalization Process of Firms: A Critical Analysis, Journal of International Business Studies, 24, 1993, pp. 209-231.

Andersen, T. J. , Integrating the Strategy Formation Process: An International Perspective, European Management Journal, 22, 2004, pp. 263-272.

Andersen, T. J./Foss, N. J., Strategic Opportunity and Economic Performance in Multinational Entreprises: The Role and Effects of Communication and Information Technology, Journal of International Management, 2005 (forthcoming).

Annavarjula, M./Beldona, S., Multinationality-Performance Relationship: A Review and Reconciliation, The International Journal of Organizational Analysis, 8, 2000, pp. 48-67.

Argote, L., Organizational Learning: Creating, Retaining, and Transferring Knowledge, Boston: Kluwer 1999.

Barkema, H. G./ Bell, J. H. J./Pennings, J. M., Foreign Entry, Cultural Barriers, and Learning, Strategic Management Journal, 17, 1996, pp. 151-166.

Bartlett, C. A./Ghoshal, S., Managing Across Borders: The Transnational Solution $2^{\text {nd }}$ ed., London: Random House 1998.

Beamish, P./Morrison, A./Rosenzweig, P./Inkpen, A., International Management: Text and Cases, $4^{\text {th }}$ ed., Homewood, IL: Irwin McGraw Hill 2000.

Boddewyn, J. J., Political Aspects of MNE Theory, Journal of International Business Studies, 19, 1988, pp. 341-363.

Buckley, P. J./Casson, M. C., The Future of the Multinational Enterprise, London: Macmillan 1976.

Buhner, C. H., Assessing the Internationalization Diversification of West German Corporations, Strategic Management Journal, 8, 1987, pp. 25-37.

Caves, R. E., Industrial Corporations: The Industrial Economics of Foreign Investment, Economica, 38, 1971, pp. 1-27.

Cohen, W. M./Levinthal, D. A., Absorptive Capacity: A New Perspective on Learning and Innovation, Administrative Science Quarterly, 35, 1990, pp. 128-152.

Contractor, F. J./Kundu, S. K./Hsu, C., A Three-Stage Theory of International Expansion: The Link Between Multinationality and Performance in the Service Sector, Journal of International Business Studies, 34, 2003, pp. 5-19.

Daniels, J. D./Bracker, J., Profit Performance: Do Foreign Operations Make a Difference?, Management International Review, 29, 1989, pp. 46-56.

Davidson, W. H., The Location of Foreign Investment Activity, Journal of International Business Studies, Fall, 1980, pp. 9-23.

Davidson, W. H., Market Similarity and Market Selection: Implications for International Marketing Strategy, Journal of Business Research, 11, 1983, pp. 439-456.

Desouza, K./Evaristo, R., Global Knowledge Management Strategies, European Management Journal, 21, 2003, pp. 62-67.

Dunning, J. H., The Eclectic Paradigm of International Production: A Restatement of Some Possible Extensions, Journal of International Business Studies, 19, 1988, pp. 1-32. 
Egelhoff, W. G., Strategy and Structure in Multinational Corporations: A Revision of the Stopford and Wells Model, Strategic Management Journal, 9, 1988, pp. 1-14.

Fama, E. F./French, K. R., The Cross-Section of Expected Stock Returns, Journal of Finance, 47, 1992, pp. 427-465.

Foss, N. J./Pedersen, T., Transferring Knowledge in MNCs: The Role of Subsidiary Knowledge and Organizational Context, Journal of International Management, 8, 2002, pp. 49-67.

Galbraith, J. R., Organization Design, Reading, MA: Addison-Wesley 1977.

Geringer, M. J./Beamish, P. W./daCosta, R. C.,Diversification Strategy and Internationalization: Implications for MNE Performance, Strategic Management Journal, 10, 1989, pp. 109-119.

Geringer, J./Tallman, S./Olsen, D., Product and International Diversification Among Japanese Multinational Firms, Strategic Management Journal, 21, 2000, pp. 51-80.

Gomes, L./Ramaswamy, K., An Empirical Examination of the Form of the Relationship Between Multinationality and Performance, Journal of International Business Studies, 30, 1999, pp. 173-188.

Gongming, Q., Multinationality and Performnce for the Largest US Firms 1981-92, Multinational Business Review, 6, 1998, pp. 44-51.

Govindarajan, V./Gupta, A. K., The Quest for Global Dominance: Transforming Global Presence Into Global Competitive Advantage, San Francisco: Jossey-Bass 2001.

Grant, R. M., Multinationality and Performance Among British Manufacturing Companies, Journal of International Business Studies, 22, 1987, pp. 249-263.

Grant, R. M., Toward a Knowledge-Based Theory of the Firm, Strategic Management Journal, 17, 1996, pp. 109-122.

Grant, R. M./Jammine, A. P./Thomas, H., Diversity, Diversification and Profitability Among British Manufacturing Companies, 1972-1984, Academy of Management Journal, 31, 1988, pp. 771-801.

Hennart, J. F., The Theoretical Rational for a Multinationality-Performance Relationship, Management International Review, 47, 2007, pp. 423-452.

Hill, C. W./Phan, P., CEO Tenure as a Determinant of CEO Pay, Academy of Management Journal, 34, 1991, pp. 707-717.

Hitt, M. A./Hoskisson, R. E./Kim, H., International Diversification: Effects on Innovation and Firm Performance in Product-Diversified Firms, Academy of Management Journal, 40,1997, pp. 767-798.

Hymer, S. H., A Study of Foreign Direct Investment, Cambridge, MA: MIT Press 1976.

Inkpen, A. C./Dinur, A., Knowledge Management Processes and International Joint Ventures, Organization Science, 9, 1998, pp.454-468.

Johanson, J./Vahlne, J. E., The Internationalization Process of the Firm: A Model of Knowledge Development and Increasing Foreign Commitments, Journal of International Business Studies, 8, 1977, pp. 23-32.

Johanson, J./Vahlne, J. E., The Mechanism of Internationalization, International Marketing Review, 7(4), 1990, pp. 1-24.

Jones, G. R./Hill, C. W. L., Transaction Cost Analysis of Strategy-Structure Choice, Strategic Management Journal, 9, 1988, pp.159-172.

Katrishen, F. A./Scordis, N. A., Economies of Scale in Services: A Study of Multinational Insurers, Journal of International Business Studies, 29, 1998, pp. 305-323.

Kleinbaum, D. G./Kupper, L. K./Muller, K. E./Nizam, A., Applied Regression Analysis and Other Multivariate Methods $3^{\text {rd }}$ ed., Pacific Grove: Duxbury Press 1998. 
Kobrin, S. J., An Empirical Analysis of the Determinants of Global Integration, Strategic Management Journal, 12, 1991, pp. 17-37.

Kogut, B., A Note on Global Strategies, Strategic Management Journal, 10, 1989, pp. 383-389.

Kogut, B./Singh, H., The Effects of National Culture on the Choice of Entry Mode, Journal of International Business Studies, Fall, 1988, pp. 411-432.

Kogut, B./Zander, U., Knowledge of the Firm, Combinative Capabilities, and the Replication of Technology,” Organization Science, 3, 1992, pp. 383-397.

Kogut, B./Zander, U., Knowledge of the Firm and the Evolutionary Theory of the Multinational Corporation, Journal of International Business Studies, 15, 1993, pp.151-168.

Kogut, B./Kulatilaka, N., Operating Flexibility, Global Manufacturing and the Option Value of a Multinational Network, Management Science, 40, 1994, pp. 123-138.

Kotabe, M./Srinivasan, S. S./Aulakh, P. S., Multinationality and Firm Performance: The Moderating Role of R\&D and Marketing Capabilities, Journal of International Business Studies, 33, 2002, pp. 79-97.

Lessard, D. R., World, Country, and Industry Relationships in Equity Returns: Implications for Risk Reduction through International Diversification, Financial Analysts Journal, 32, 1976, pp. 32-38.

Lord, M. D./Ranft, A. L., Organizational Learning About New International Markets: Exploring the Internal Transfer of Local Market Knowledge, Journal of International Business Studies, 31, 2000, pp. 573589.

Lu, J./Beamish, P. W., International Diverfication and Firm Performance: The S-Curve Hypothesis, Academy of Management Journal, 47, 2004, pp. 598-609.

Michel, A./Shaked, I., 'Multinational Corporations vs. Domestic Corporations: Financial Performance and Characteristics, Journal of International Business Studies, 17, 1986, pp. 89-101.

Mishra, C. S./Gobeli, D. H., Managerial Incentives, Internationalization, and Market Valuation of Multinational Firms, Journal of International Business Studies, 1998, 29, pp. 583-597.

Mudambi, R., Knowledge Management in Multinational Firms, Journal of International Management, 8, 2002, pp. 1-9.

Papadopoulos, N./Denis, J., Inventory, Taxonomy and Assessment of Methods for International Market Selection, International Marketing Review, Autumn, 1988, pp. 38-51.

Porter, M., Changing Patterns of International Competition, California Management Review, 28, 1986, pp. 940.

Porter, M., What is Strategy?, Harvard Business Review, xx, 1996, pp. 61-78.

Prahalad, C. K./Doz, Y. L., The Multinational Mission, New York: Free Press 1987.

Raihi-Belkaoui, A., The Effects of the Degree of Internationalization on Firm Performance, International Busines Review, 7, 1998, pp. 315-321.

Ramaswamy, K., Multinationality, Configuration, and Performance: A Study of MNEs in the US Drug and Pharmaceutical Industry, Journal of International Management, 1, 1995, pp. 231-253.

Ramaswamy, K./Kroeck, K. G./Renforth, W., Measuring the Degree of Internationalization of Firms: A Comment, Journal of International Business Studies, 27, 1996, pp. 167-177.

Reeb, D. M./Kwok, C. C. Y./Baek, Y. H., Systematic Risk of the Multinational Corporation, Journal of International Business Studies, 29, 1998, pp. 263-279.

Riahi-Belkaoui, A., The Effects of the Degree of Internationalization on Firm Performance, International Busines Review, 7, 1998, pp. 315-321.

Rosenzweig, P. M./Singh, J. V., Organizational Environments and the Multinational Enterprise,” Academy of 
Management Review, 16, 1991, pp. 340-361.

Roth, K./Donnell, S., Foreign Subsidiary Compensation Strategy: An Agency Theory Perspective, Academy of Management Journal, 39, 1996, pp. 678-703.

Ruigrok, W./Wagner, H., Internationalization and Performance: An Organizational Learning Perspective, Management International Review, 43, 2003, pp. 63-83.

Ruigrok, W./Wagner, H./Amann W., The Form of the Internationalization Relationship: "Universal” or “Context Dependent”?, paper prepared for the AIB/JIBS Paper Development Workshop, 2004, Stockholm, Sweden.

Rugman, A. M., Inside the Multinational: The Economics of International Markets, London: Croom Helm 1981.

Rugman, A.M./Hodgetts, R. M. , International Business, 3rd ed., Harlow, UK: Pearson Education, 2003.

Rumelt, R., How Much Does Industry Matter?, Strategic Management Journal, 12, 1991, pp. 167-185.

Schmalansee, R., Do Markets Differ Much?, American Economic Review, 75, 1985, pp. 341-351.

Siddharthan, N. S./Lall, S., Recent Growth of the Largest US Multinationals, Oxford Bulletin of Economic Statistics, 44, 1982, pp 1-13.

Simerli, R. L./Li, M., Environmental Dynamism, Capital Structure and Performance: A Theoretical Integration and an Empirical Test, Strategic Management Journal, 21, 2000, pp. 31-50.

Stabell, C. B./Fjelstad, Ø. D., Configuring Value for Competitive Advantage, Strategic Management Journal, 19, 1998, pp. 413-437.Sullivan, D., The "Threshold of Internationalization”: Replication, Extension, and Reinterpretation, Management International Review, 34, 1994, pp. 165-186.

Tallman, S./Li, J., Effects of International Diversity and Product Diversity on the Performance of Multinational Firms, Academy of Management Journal, 39, 1996, pp. 179-196.

Teece, D. J., The Multinational Enterprise: Market Failure and Market Power Considerations, Sloan Management Review, 1981, Spring, 1981, pp. 3-17.

Teece, D. J., Profiting from Technological Innovation: Implications for Integration, Collaboration, Licensing and Public Policy, Research Policy, 15, 1986, pp. 285-305.

Vernon, R., International Investment and International Trade in the Product Life Cycle, Quarterly Journal of Economics, 80, 1966, pp. 190-207.

Vernon, R., Sovereignty at Bay: The Multinational Spread of US Enterprises, New York: Basic Books 1971.

Yip, G. S., Total Global Strategy, Upper Saddle River: Prentice-Hall 1995.

Zaheer, S., Overcoming the Liabilities of Foreignness, Academy of Management Journal, 38, 1995, pp. 341363.

Zaheer, S./Mosakowski, E., The Dynamics of the Liability of Foreignness: A Global Study of Survival in Financial Services, Strategic Management Journal, 18, 1997, pp. 439-464. 
Figure 1. The Performance Relationship of Multinationality as Determined by Underlying Cost/Benefit Functions

a. Negative Linear Performance Relationship
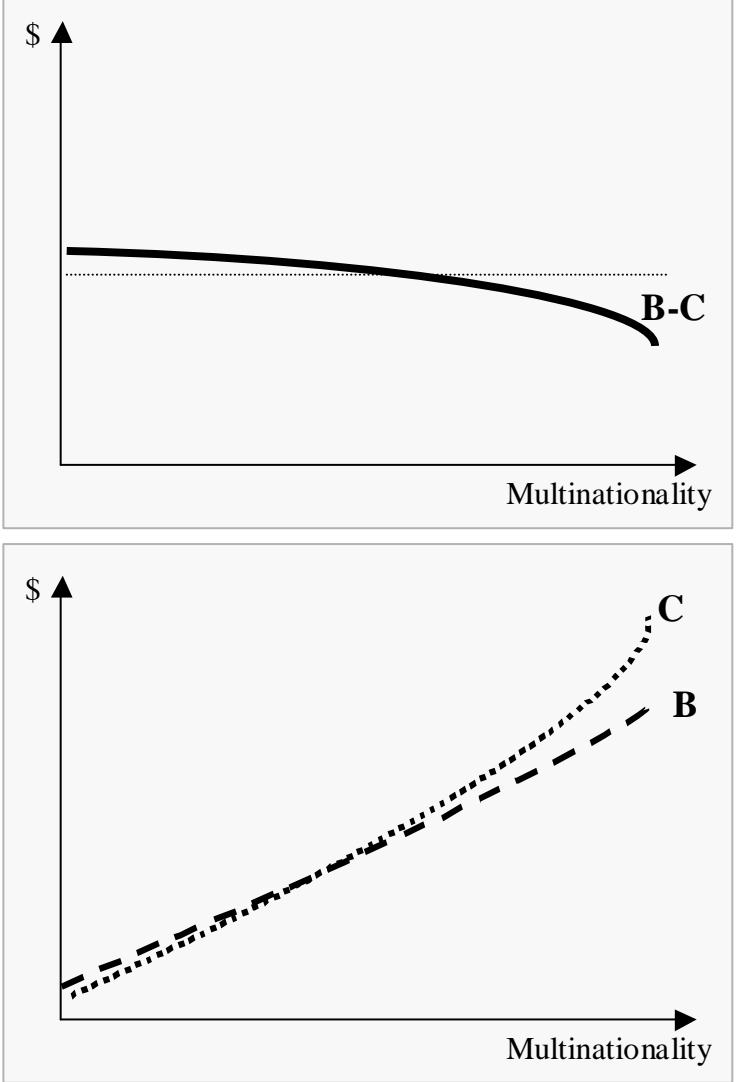

b. Positive Linear Performance Relationship
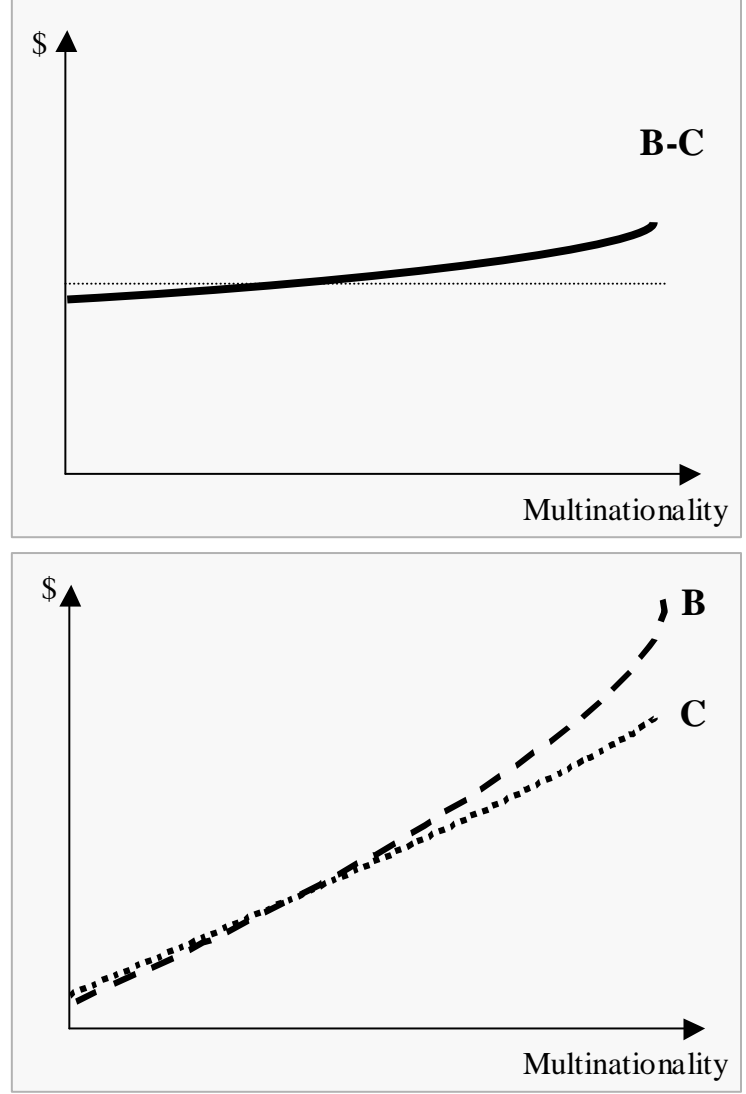
Figure 2. The Performance Relationship of Multinationality as Determined by Underlying Cost/Benefit Functions

a. Inverse U-Curve Performance Relationship
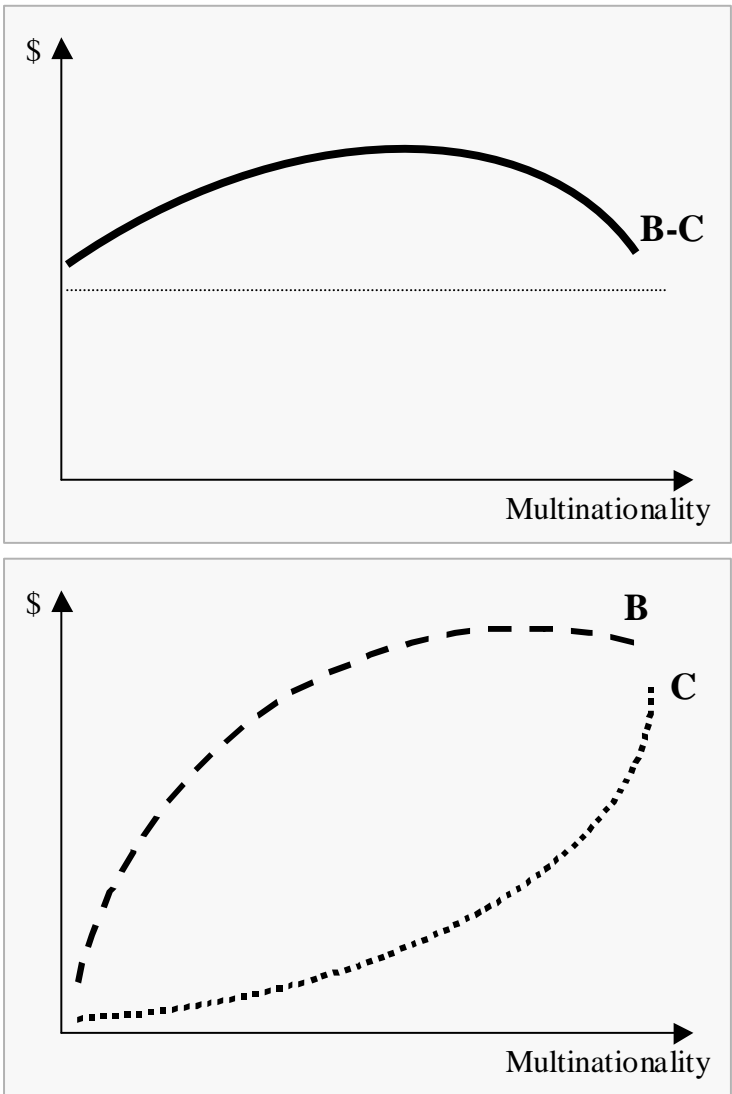

b. U-Curve Performance Relationship
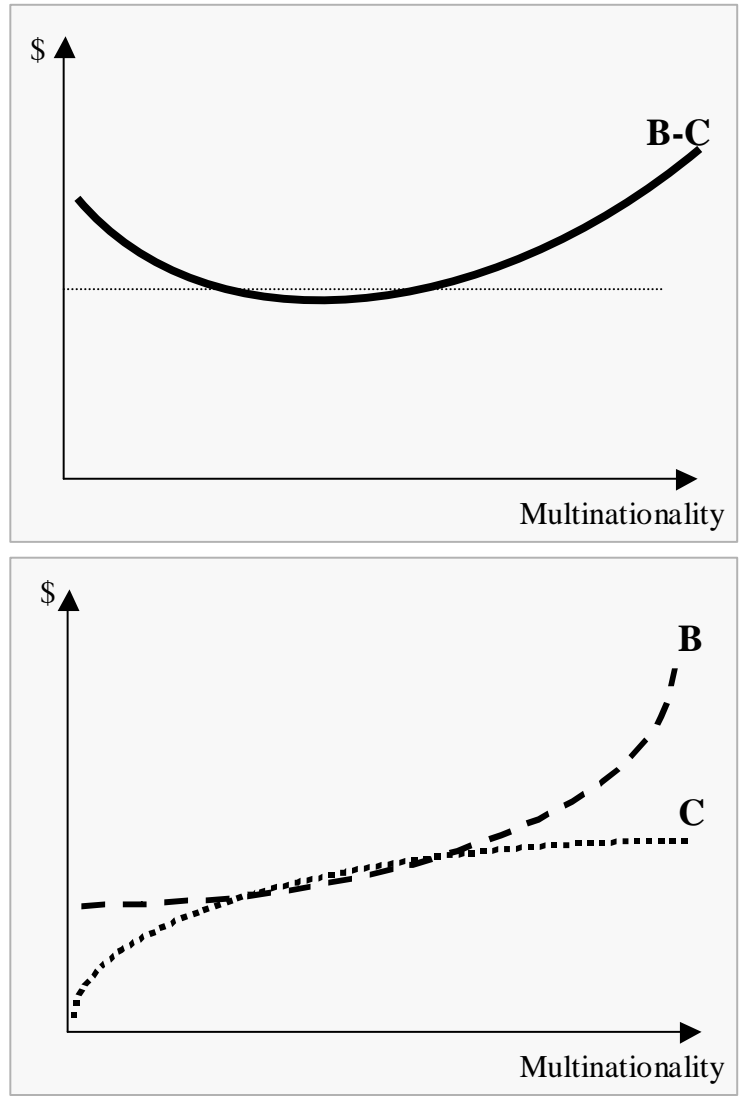
Figure 3. The Performance Relationship of Multinationality as Determined by Underlying Cost/Benefit Functions

a. S-Curve Performance Relationship
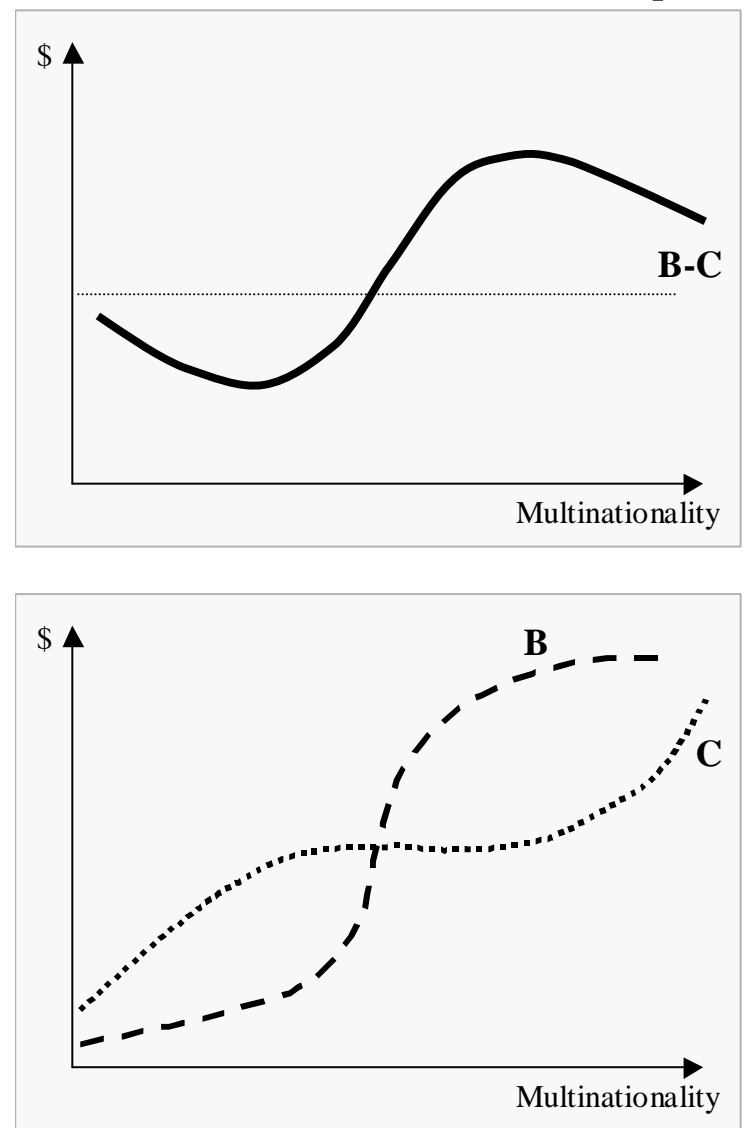

b. Inverse S-Curve Performance Relationship
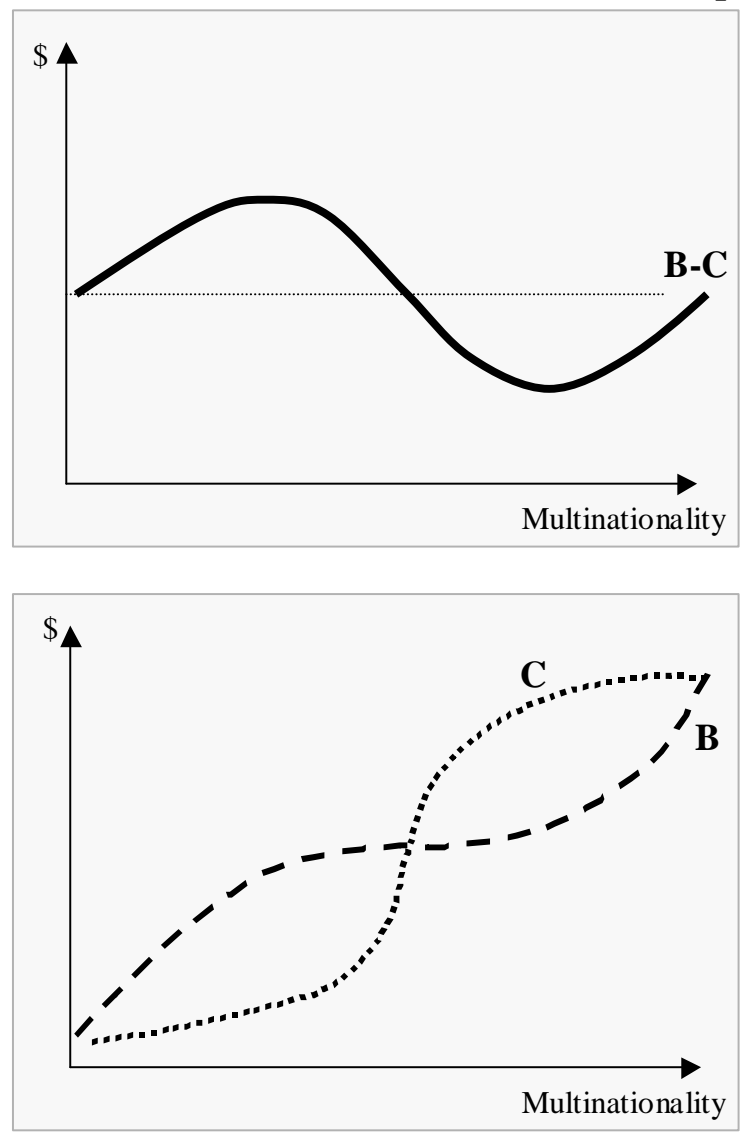
Table 1. Descriptive Statistics and Correlation Coefficients $(n=1,175)$

\begin{tabular}{|c|c|c|c|c|c|c|c|c|c|}
\hline & & Mean & S.D. & 1 & 2 & 3 & 4 & 5 & 6 \\
\hline 1 & ROI (return on investment) & 7.55 & 8.74 & - & - & - & - & - & - \\
\hline 2 & ROA (return on asset) & 4.25 & 5.69 & $.872^{* *}$ & - & - & - & - & - \\
\hline 3 & Organizational size (ln[assets]) & 7.85 & 1.60 & -.034 & $.079^{* *}$ & - & - & - & - \\
\hline 4 & Financial leverage & 1.13 & 2.08 & $-.144^{* *}$ & $-.098^{* *}$ & $.236^{* *}$ & - & - & - \\
\hline 5 & R\&D intensity & 1.72 & 2.44 & $.112^{* *}$ & $.070^{* *}$ & $-.073^{* *}$ & $-.100^{* *}$ & - & - \\
\hline 6 & Market-to-book ratio & 1.21 & 2.36 & $.256^{* *}$ & $.202^{* *}$ & $-.391^{* *}$ & $-.206^{* *}$ & $.306^{* *}$ & - \\
\hline 7 & Multinationality $(\ln [1+c t y])$ & 0.36 & 0.48 & $.162^{* *}$ & $.168^{* *}$ & $.203^{* *}$ & $-.048^{* *}$ & $.312^{* *}$ & $.074^{*}$ \\
\hline
\end{tabular}

${ }^{+} p<0.10 ;{ }^{*} p<0.05 ;{ }^{* *} p<0.01$ 
Table 2. Regression Analyses - Cross Sectional Sample (Standardized Regression Coefficients, n=1,175)

Dependent variable:

Organizational size (ln[assets])

Financial leverage

R\&D intensity

Market-to-book value

Primary ${ }^{\mathrm{a}}$

Household goods ${ }^{\mathrm{b}}$

Electronics, machinery ${ }^{c}$

Transportation $^{\mathrm{d}}$

Telecommunication ${ }^{\mathrm{e}}$

Energy $^{f}$

Wholesale $^{g}$

Retail $^{\mathrm{h}}$

Financial institutions

Data programming services

Multinationality $(\ln [1+c t y])$

Multinationality $\left(\ln [1+c t y]^{2}\right)$

Multinationality $\left(\ln [1+c t y]^{3}\right)$

Multiple $\mathbf{R}^{2}$

Adjusted $\mathrm{R}^{2}$

F-significance

\begin{tabular}{|c|c|c|c|c|c|c|c|c|c|}
\hline \multicolumn{4}{|c|}{ ROI (return on investment) } & \multicolumn{5}{|c|}{ ROA (return on assets) } & \\
\hline & $.194^{* *}$ & $.146^{* *}$ & $.127^{* *}$ & $.124^{* *}$ & & $.123^{* *}$ & $.065^{+}$ & .055 & .052 \\
\hline$-.074^{*}$ & $-.069^{*}$ & $-.071^{*}$ & $-.070^{*}$ & & $-.078^{* *}$ & $-.074^{* *}$ & $-.075^{* *}$ & $-.074^{* *}$ & \\
\hline-.029 & -.043 & -.050 & -.049 & & $-.062^{+}$ & $.070^{*}$ & $-.074^{*}$ & $-.073^{*}$ & \\
\hline $.294^{* *}$ & $.293^{* *}$ & $.293^{* *}$ & $.281^{* *}$ & & $.304^{* *}$ & $.297^{* *}$ & $.292^{* *}$ & $.290^{* *}$ & \\
\hline .021 & .032 & .032 & .032 & & .054 & .053 & .053 & .053 & \\
\hline $.130^{* *}$ & $.125^{*}$ & $.125^{*}$ & $.125^{* *}$ & & $.182^{* *}$ & $.164^{* *}$ & $.163^{* *}$ & $.164^{* *}$ & \\
\hline $.087^{+}$ & .065 & .069 & .074 & & $.136^{* *}$ & $.106^{*}$ & $.109^{*}$ & $.112^{*}$ & \\
\hline .033 & .038 & .041 & .041 & & .050 & .047 & .049 & .049 & \\
\hline$-.154^{* *}$ & $-.142^{* *}$ & $-.144^{* *}$ & $-.143^{* *}$ & & $-.150^{* *}$ & $-.148^{* *}$ & $-.150^{* *}$ & $-.149^{* *}$ & \\
\hline-.042 & -.014 & -.015 & -.014 & & -.001 & .013 & .012 & .013 & \\
\hline .013 & .013 & .013 & .014 & & .025 & .016 & .016 & .017 & \\
\hline $.110^{* *}$ & $.124^{* *}$ & $.123^{* *}$ & $.124^{* *}$ & & $.122^{* *}$ & $.121^{* *}$ & $.120^{* *}$ & $.121^{* *}$ & \\
\hline $.101^{*}$ & $.141^{* *}$ & $.140^{* *}$ & $.142^{* *}$ & & -.020 & .002 & .002 & .003 & \\
\hline-.053 & $-.065^{+}$ & $-.061^{+}$ & $-.061^{+}$ & & -.044 & $-.062^{+}$ & $-.060^{+}$ & $-.059^{+}$ & \\
\hline - & $.132^{* *}$ & -.080 & .072 & & - & $.096^{* *}$ & -.016 & .119 & \\
\hline- & - & $.228^{* *}$ & -.176 & & - & - & .121 & -.238 & \\
\hline- & - & - & .266 & & - & - & - & .236 & \\
\hline .147 & .158 & .163 & .164 & & .159 & .162 & .164 & 164 & \\
\hline .136 & .147 & .151 & .151 & & .148 & .151 & .151 & .151 & \\
\hline .000 & .000 & .000 & .000 & & .000 & .000 & .000 & .000 & \\
\hline
\end{tabular}

$p<0.10 ;{ }^{*} p<0.05 ;{ }^{* *} p<0.01$

a SIC code: 100-1731; ${ }^{\text {b }}$ SIC code: $2000-2911 ;{ }^{\text {c }}$ SIC code: $3011-3990 ;{ }^{\text {d }}$ SIC code: 4011-4522; ${ }^{\text {e }}$ SIC code: $4812-4899 ;{ }^{\text {f }}$ SIC code: $4911-4991 ;{ }^{\text {g }}$ SIC code: $5000-5190$;

${ }^{\text {h }}$ SIC code: 5200-5735; ${ }^{\text {i }}$ SIC code: $6021-6799 ;{ }^{j}$ SIC code: $7370-7377$. 
Table 3. Regression Analyses - Manufacturing Companies ${ }^{\text {a }}$ (Standardized Regression Coefficients, $n=532$ )

\begin{tabular}{|c|c|c|c|c|c|c|c|c|c|c|}
\hline \multirow{2}{*}{$\begin{array}{l}\text { Dependent variable: } \\
\text { Organizational size (ln[assets]) }\end{array}$} & \multicolumn{4}{|c|}{ ROI (return on investment) } & \multicolumn{5}{|c|}{ ROA (return on assets) } & \multirow[b]{2}{*}{$.144^{* *}$} \\
\hline & & $.260^{* *}$ & $.223^{* *}$ & $.203^{* *}$ & $.201^{* *}$ & & $.174^{* *}$ & $.146^{* *}$ & $.144^{* *}$ & \\
\hline R\&D intensity & $-.088^{*}$ & $-.096^{*}$ & $-.097^{*}$ & $-.094^{*}$ & & $-.123^{* *}$ & $-.129^{* *}$ & $-.129^{* *}$ & $-.129^{* *}$ & \\
\hline Market-to-book value & $.354^{* *}$ & $.354^{* *}$ & $.342^{* *}$ & $.340^{* *}$ & & $.393^{* *}$ & $.393^{* *}$ & $.392^{* *}$ & $.392^{* *}$ & \\
\hline Electronics, machinery $^{\mathrm{c}}$ & .087 & .043 & .050 & .052 & & .061 & .029 & .030 & .030 & \\
\hline Multinationality $(\ln [1+c t y])$ & - & $.118^{* *}$ & -.034 & .091 & & - & $.086^{+}$ & .071 & .078 & \\
\hline Multinationality $\left(\ln [1+c t y]^{2}\right)$ & - & - & .164 & -.174 & & - & - & .016 & -.004 & \\
\hline Multinationality $\left(\ln [1+c t y]^{3}\right)$ & - & - & - & .222 & & - & - & - & .013 & \\
\hline Multiple $\mathbf{R}^{2}$ & .141 & .152 & .154 & .155 & & .148 & .154 & .154 & .154 & \\
\hline F-significance & .000 & .000 & .000 & .000 & & .000 & .000 & .000 & .000 & \\
\hline
\end{tabular}

${ }^{+} p<0.10 ;{ }^{*} p<0.05 ;{ }^{* *} p<0.01$

${ }^{\text {a }}$ SIC code: 2000-3990; ${ }^{\mathrm{b}}$ SIC code: 2000-2911; ' SIC code: 3011-3990. 
Table 4. Regression Analyses - Trading Companies ${ }^{\mathrm{a}}$ (Standardized Regression Coefficients, $\mathrm{n}=194$ )

Dependent variable:

Organizational size (ln[assets])

Financial leverage

R\&D intensity

Market-to-book value

Wholesale $^{\mathrm{b}}$

Retail $^{\mathrm{C}}$

Multinationality $(\ln [1+c t y])$

Multinationality $\left(\ln [1+c t y]^{2}\right)$

Multinationality $\left(\ln [1+c t y]^{3}\right)$

Multiple $\mathbf{R}^{2}$

Adjusted $\mathbf{R}^{2}$

F-significance

\begin{tabular}{|c|c|c|c|c|c|c|c|c|c|}
\hline \multicolumn{5}{|c|}{ ROI (return on investment) } & \multicolumn{4}{|c|}{ ROA (return on assets) } & \multirow[b]{2}{*}{-.018} \\
\hline & -.025 & -.047 & -.046 & -.036 & & -.012 & -.034 & -.032 & \\
\hline-.082 & -.082 & -.082 & -.079 & & -.004 & -.004 & -.005 & -.001 & \\
\hline-.026 & -.036 & -.037 & -.031 & & -.052 & -.062 & -.065 & -.057 & \\
\hline $.592^{* *}$ & $.589^{* *}$ & $.588^{* *}$ & $.585^{* *}$ & & $.724^{* *}$ & $.721^{* *}$ & $.717^{* *}$ & $.713^{* *}$ & \\
\hline-.105 & -.111 & -.109 & -.104 & & $-.120^{+}$ & $-.125^{+}$ & $-.118^{+}$ & -.111 & \\
\hline-.050 & -.038 & -.037 & -.030 & & -.086 & -.074 & -.068 & -.059 & \\
\hline- & .083 & .111 & .474 & & - & .085 & .206 & $.725^{*}$ & \\
\hline- & - & -.030 & -.980 & & - & - & -.129 & $-1.490^{+}$ & \\
\hline- & - & - & .625 & & - & - & - & $.893^{+}$ & \\
\hline 395 & .401 & .401 & .405 & & .522 & .529 & .531 & .538 & \\
\hline .373 & .376 & .372 & .373 & & .505 & .508 & .508 & .513 & \\
\hline .000 & .000 & .000 & .000 & & .000 & .000 & .000 & .000 & \\
\hline
\end{tabular}

$p<0.10 ;{ }^{*} p<0.05 ;{ }^{* *} p<0.0$

SIC code: 5000-5990; ${ }^{\text {b }}$ SIC code: 5000-5190; ${ }^{\text {c }}$ SIC code: 5200-5735. 
Table 5. Regression Analyses - Knowledge-Based Service Companies ${ }^{\mathrm{a}}$ (Standardized Regression Coefficients, n=145)

Dependent variable:

Organizational size (ln[assets])

Financial leverage

R\&D intensity

Market-to-book value

Data programming services ${ }^{b}$

Multinationality $(\ln [1+c t y])$

Multinationality $\left(\ln [1+c t y]^{2}\right)$

Multinationality $\left(\ln [1+c t y]^{3}\right)$

Multiple $\mathbf{R}^{2}$

Adjusted $\mathbf{R}^{2}$

F-significance

\begin{tabular}{|c|c|c|c|c|c|c|c|c|}
\hline \multicolumn{4}{|c|}{ ROI (return on investment) } & & \multicolumn{4}{|c|}{ ROA (return on assets) } \\
\hline & $.228^{*}$ & .146 & .093 & .094 & & $.234^{*}$ & .070 & .023 \\
\hline$-.258^{* *}$ & $-.224^{*}$ & $-.229^{*}$ & $-.229^{*}$ & & $-.240^{*}$ & $.227^{*}$ & $-.231^{*}$ & $-.230^{*}$ \\
\hline .066 & .022 & .013 & .014 & & .013 & .012 & .004 & .005 \\
\hline-.005 & .018 & -.012 & -.012 & & -.119 & -.179 & $-.205^{+}$ & $-.205^{+}$ \\
\hline .026 & -.011 & -.002 & -.002 & & .135 & .105 & .113 & .113 \\
\hline- & $.204^{*}$ & -.078 & -.098 & & - & .092 & -.157 & -.198 \\
\hline- & - & .318 & .371 & & - & - & .280 & .389 \\
\hline- & - & - & -.036 & & - & - & - & -.073 \\
\hline .099 & .127 & .138 & .138 & & .104 & .086 & .094 & .094 \\
\hline .060 & .082 & .087 & .080 & & .065 & .039 & .041 & .034 \\
\hline .023 & .023 & .009 & .016 & & .017 & .086 & .090 & .136 \\
\hline
\end{tabular}

${ }^{+} p<0.10 ;{ }^{*} p<0.05 ;{ }^{* *} p<0.01$

a SIC code: $7200-8742 ;{ }^{\circ}$ SIC code: $7370-7377$ 
Table 6. Regression Analyses - Capital-Based Service Companies ${ }^{\mathrm{a}}$ (Standardized Regression Coefficients, $\mathrm{n}=169$ )

Dependent variable:

Organizational size (ln[assets])

Financial leverage

R\&D intensity

Market-to-book value

Telecommunication

Energy $^{c}$

Multinationality $(\ln [1+c t y])$

Multinationality $\left(\ln [1+c t y]^{2}\right)$

Multinationality $\left(\ln [1+c t y]^{3}\right)$

Multiple $\mathbf{R}^{2}$

Adjusted $\mathbf{R}^{2}$

F-significance

\begin{tabular}{|c|c|c|c|c|c|c|c|c|c|}
\hline \multicolumn{4}{|c|}{ ROI (return on investment) } & \multicolumn{5}{|c|}{ ROA (return on assets) } & \multirow[b]{2}{*}{$.386^{* *}$} \\
\hline & $.321^{* *}$ & $.367^{* *}$ & $.361^{* *}$ & $.365^{* *}$ & & $.330^{* *}$ & $.389^{* *}$ & $.383^{* *}$ & \\
\hline .076 & .084 & .090 & $.194^{+}$ & & $.101^{+}$ & $.112^{+}$ & $.118^{*}$ & $.134^{*}$ & \\
\hline-.030 & -.018 & -.034 & -.052 & & -.040 & -.024 & -.043 & -.063 & \\
\hline $.540^{* *}$ & $.566^{* *}$ & $.567^{* *}$ & $.573^{* *}$ & & $.560^{* *}$ & $.594^{* *}$ & $.595^{* *}$ & $.602^{* *}$ & \\
\hline$-.678^{* *}$ & $-.710^{* *}$ & $-.726^{* *}$ & $-.723^{* *}$ & & $-.700^{* *}$ & $-.741^{* *}$ & $-.761^{* *}$ & $-.757^{* *}$ & \\
\hline$-.158^{+}$ & $-.208^{*}$ & $-.217^{*}$ & $-.219^{*}$ & & $-.134^{+}$ & $-.199^{*}$ & $-.210^{*}$ & $-.212^{*}$ & \\
\hline- & $-.118^{+}$ & $-.302^{+}$ & .120 & & - & $-.155^{*}$ & $-.372^{*}$ & .088 & \\
\hline - & - & .202 & -.914 & & - & - & .238 & -.978 & \\
\hline- & - & - & .748 & & - & - & - & .816 & \\
\hline .400 & .411 & .416. & .422 & & .442 & .460 & .467 & .474 & \\
\hline .374 & .382 & .383 & .385 & & .418 & .433 & .437 & .441 & \\
\hline .000 & .000 & .000 & .000 & & .000 & .000 & .000 & .000 & \\
\hline
\end{tabular}

$p<0.10 ;{ }^{*} p<0.05 ;{ }^{* *} p<0.0$

SIC code: 4011-4991; ${ }^{\text {b }}$ SIC code: 4812-4899; ${ }^{\text {c }}$ SIC code: 4911-4991. 


\section{SMG - Working Papers \\ www.cbs.dk/smg \\ 2003}

2003-1: Nicolai J. Foss, Kenneth Husted, Snejina Michailova, and Torben Pedersen: Governing Knowledge Processes: Theoretical Foundations and Research Opportunities.

2003-2: Yves Doz, Nicolai J. Foss, Stefanie Lenway, Marjorie Lyles, Silvia Massini, Thomas P. Murtha and Torben Pedersen: Future Frontiers in International Management Research: Innovation, Knowledge Creation, and Change in Multinational Companies.

2003-3: Snejina Michailova and Kate Hutchings: The Impact of In-Groups and OutGroups on Knowledge Sharing in Russia and China CKG Working Paper.

2003-4: Nicolai J. Foss and Torben Pedersen: The MNC as a Knowledge Structure: The Roles of Knowledge Sources and Organizational Instruments in MNC Knowledge Management CKG Working Paper.

2003-5: Kirsten Foss, Nicolai J. Foss and Xosé H. Vázquez-Vicente: “Tying the Manager’s Hands": How Firms Can Make Credible Commitments That Make Opportunistic Managerial Intervention Less Likely CKG Working Paper.

2003-6: Marjorie Lyles, Torben Pedersen and Bent Petersen: Knowledge Gaps: The Case of Knowledge about Foreign Entry.

2003-7: Kirsten Foss and Nicolai J. Foss: The Limits to Designed Orders: Authority under "Distributed Knowledge" CKG Working Paper.

2003-8: Jens Gammelgaard and Torben Pedersen: Internal versus External Knowledge Sourcing of Subsidiaries - An Organizational Trade-Off.

2003-9: Kate Hutchings and Snejina Michailova: Facilitating Knowledge Sharing in Russian and Chinese Subsidiaries: The Importance of Groups and Personal Networks Accepted for publication in Journal of Knowledge Management.

2003-10: Volker Mahnke, Torben Pedersen and Markus Verzin: The Impact of Knowledge Management on MNC Subsidiary Performance: the Role of Absorptive Capacity CKG Working Paper.

2003-11: Tomas Hellström and Kenneth Husted: Mapping Knowledge and Intellectual Capital in Academic Environments: A Focus Group Study Accepted for publication in Journal of Intellectual Capital CKG Working Paper.

2003-12: Nicolai J Foss: Cognition and Motivation in the Theory of the Firm: Interaction or "Never the Twain Shall Meet"? Accepted for publication in Journal des Economistes et des Etudes Humaines CKG Working Paper.

2003-13: Dana Minbaeva and Snejina Michailova: Knowledge Transfer and Expatriation Practices in MNCs: The Role of Disseminative Capacity.

2003-14: Christian Vintergaard and Kenneth Husted: Enhancing Selective Capacity Through Venture Bases. 


\section{4}

2004-1: Nicolai J. Foss: Knowledge and Organization in the Theory of the Multinational Corporation: Some Foundational Issues

2004-2: Dana B. Minbaeva: HRM Practices and MNC Knowledge Transfer

2004-3: Bo Bernhard Nielsen and Snejina Michailova: Toward a Phase-Model of Global Knowledge Management Systems in Multinational Corporations

2004-4: Kirsten Foss \& Nicolai J Foss: The Next Step in the Evolution of the RBV: Integration with Transaction Cost Economics

2004-5: Teppo Felin \& Nicolai J. Foss: Methodological Individualism and the Organizational Capabilities Approach

2004-6: Jens Gammelgaard, Kenneth Husted, Snejina Michailova: Knowledge-sharing Behavior and Post-acquisition Integration Failure

2004-7: Jens Gammelgaard: Multinational Exploration of Acquired R\&D Activities

2004-8: Christoph Dörrenbächer \& Jens Gammelgaard: Subsidiary Upgrading? Strategic Inertia in the Development of German-owned Subsidiaries in Hungary

2004-9: Kirsten Foss \& Nicolai J. Foss: Resources and Transaction Costs: How the Economics of Property Rights Furthers the Resource-based View

2004-10: Jens Gammelgaard \& Thomas Ritter: The Knowledge Retrieval Matrix: Codification and Personification as Separate Strategies

2004-11: Nicolai J. Foss \& Peter G. Klein: Entrepreneurship and the Economic Theory of the Firm: Any Gains from Trade?

2004-12: Akshey Gupta \& Snejina Michailova: Knowledge Sharing in Knowledge-Intensive Firms: Opportunities and Limitations of Knowledge Codification

2004-13: Snejina Michailova \& Kate Hutchings: Knowledge Sharing and National Culture: A Comparison Between China and Russia

\section{5}

2005-1: Keld Laursen \& Ammon Salter: My Precious - The Role of Appropriability Strategies in Shaping Innovative Performance

2005-2: Nicolai J. Foss \& Peter G. Klein: The Theory of the Firm and Its Critics: A Stocktaking and Assessment

2005-3: Lars Bo Jeppesen \& Lars Frederiksen: Why Firm-Established User Communities Work for Innovation: The Personal Attributes of Innovative Users in the Case of Computer-Controlled Music

2005-4: Dana B. Minbaeva: Negative Impact of HRM Complementarity on Knowledge Transfer in MNCs

2005-5: Kirsten Foss, Nicolai J. Foss, Peter G. Klein \& Sandra K. Klein: Austrian Capital 
Theory and the Link Between Entrepreneurship and the Theory of the Firm

2005-1: Nicolai J. Foss: The Knowledge Governance Approach

2005-2: Torben J. Andersen: Capital Structure, Environmental Dynamism, Innovation Strategy, and Strategic Risk Management

2005-3: Torben J. Andersen: A Strategic Risk Management Framework for Multinational Enterprise

2005-4: Peter Holdt Christensen: Facilitating Knowledge Sharing: A Conceptual Framework

2005-5 Kirsten Foss \& Nicolai J. Foss: Hands Off! How Organizational Design Can Make Delegation Credible

2005-6 Marjorie A. Lyles, Torben Pedersen \& Bent Petersen: Closing the Knowledge Gap in Foreign Markets - A Learning Perspective

2005-7 Christian Geisler Asmussen, Torben Pedersen \& Bent Petersen: How do we Capture "Global Specialization" when Measuring Firms' Degree of internationalization?

2005-8 Kirsten Foss \& Nicolai J. Foss: Simon on Problem-Solving: Implications for New Organizational Forms

2005-9 Birgitte Grøgaard, Carmine Gioia \& Gabriel R.G. Benito: An Empirical Investigation of the Role of Industry Factors in the Internationalization Patterns of Firms

2005-10 Torben J. Andersen: The Performance and Risk Management Implications of Multinationality: An Industry Perspective

2005-11 Nicolai J. Foss: The Scientific Progress in Strategic Management: The case of the Resource-based view

2005-12 Koen H. Heimeriks: Alliance Capability as a Mediator Between Experience and Alliance Performance: An Empirical Investigation Into the Alliance Capability Development Process

2005-13 Koen H. Heimeriks, Geert Duysters \& Wim Vanhaverbeke: Developing Alliance Capabilities: An Empirical Study

2005-14 JC Spender: Management, Rational or Creative? A Knowledge-Based Discussion

\section{6}

2006-1: Nicolai J. Foss \& Peter G. Klein: The Emergence of the Modern Theory of the Firm

2006-2: Teppo Felin \& Nicolai J. Foss: Individuals and Organizations: Thoughts on a Micro-Foundations Project for Strategic Management and Organizational Analysis

2006-3: Volker Mahnke, Torben Pedersen \& Markus Venzin: Does Knowledge Sharing 
Pay? An MNC Subsidiary Perspective on Knowledge Outflows

2006-4: Torben Pedersen: Determining Factors of Subsidiary Development

2006-5 Ibuki Ishikawa: The Source of Competitive Advantage and Entrepreneurial Judgment in the RBV: Insights from the Austrian School Perspective

2006-6 Nicolai J. Foss \& Ibuki Ishikawa: Towards a Dynamic Resource-Based View: Insights from Austrian Capital and Entrepreneurship Theory

2006-7 Kirsten Foss \& Nicolai J. Foss: Entrepreneurship, Transaction Costs, and Resource Attributes

2006-8 Kirsten Foss, Nicolai J. Foss \& Peter G. Klein: Original and Derived Judgement: An Entrepreneurial Theory of Economic Organization

2006-9 Mia Reinholt: No More Polarization, Please! Towards a More Nuanced Perspective on Motivation in Organizations

2006-10 Angelika Lindstrand, Sara Melen \& Emilia Rovira: Turning social capital into business? A study of Swedish biotech firms' international expansion

2006-11 Christian Geisler Asmussen, Torben Pedersen \& Charles Dhanaraj: Evolution of Subsidiary Competences: Extending the Diamond Network Model

2006-12 John Holt, William R. Purcell, Sidney J. Gray \& Torben Pedersen: Decision Factors Influencing MNEs Regional Headquarters Location Selection Strategies

2006-13 Peter Maskell, Torben Pedersen, Bent Petersen \& Jens Dick-Nielsen: Learning Paths to Offshore Outsourcing - From Cost Reduction to Knowledge Seeking

2006-14 Christian Geisler Asmussen: Local, Regional or Global? Quantifying MNC Geographic Scope

2006-15 Christian Bjørnskov \& Nicolai J. Foss: Economic Freedom and Entrepreneurial Activity: Some Cross-Country Evidence

2006-16 Nicolai J. Foss \& Giampaolo Garzarelli: Institutions as Knowledge Capital: Ludwig M. Lachmann's Interpretative Institutionalism

2006-17 Koen H. Heimriks \& Jeffrey J. Reuer: How to Build Alliance Capabilities

2006-18 Nicolai J. Foss, Peter G. Klein, Yasemin Y. Kor \& Joseph T. Mahoney: Entrepreneurship, Subjectivism, and the Resource - Based View: Towards a New Synthesis

2006-19 Steven Globerman \& Bo B. Nielsen: Equity Versus Non-Equity International Strategic Alliances: The Role of Host Country Governance

\section{7}

2007-1 Peter Abell, Teppo Felin \& Nicolai J. Foss: Building Micro-Foundations for the Routines, Capabilities, and Performance Links 
2007-2 Michael W. Hansen, Torben Pedersen \& Bent Petersen: MNC Strategies and Linkage Effects in Developing Countries

2007-3 Niron Hashai, Christian G. Asmussen, Gabriel R.G. Benito \& Bent Petersen: Predicting the Diversity of Foreign Entry Modes

2007-4 Peter D. Ørberg Jensen \& Torben Pedersen: Whether and What to Offshore?

2007-5 Ram Mudambi \& Torben Pedersen: Agency Theory and Resource Dependency Theory: Complementary Explanations for Subsidiary Power in Multinational Corporations

2007-6 Nicolai J. Foss: Strategic Belief Management

2007-7 Nicolai J. Foss: Theory of Science Perspectives on Strategic Management Research: Debates and a Novel View

2007-8 Dana B. Minbaeva: HRM Practices and Knowledge Transfer in MNCs

2007-9 Nicolai J. Foss: Knowledge Governance in a Dynamic Global Context: The Center for Strategic Management and Globalization at the Copenhagen Business School

2007-10 Paola Gritti \& Nicolai J. Foss: Customer Satisfaction and Competencies: An Econometric Study of an Italian Bank

2007-11 Nicolai J. Foss \& Peter G. Klein: Organizational Governance

2007-12 Torben Juul Andersen \& Bo Berhard Nielsen: The Effective Ambidextrous Organization: A Model of Integrative Strategy Making Processes.

\section{8}

2008-1 Kirsten Foss \& Nicolai J. Foss: Managerial Authority When Knowledge is Distributed: A Knowledge Governance Perspective

2008-2 Nicolai J. Foss: Human Capital and Transaction Cost Economics.

2008-3 Nicolai J. Foss \& Peter G. Klein: Entrepreneurship and Heterogeneous Capital.

2008-4 Nicolai J. Foss \& Peter G. Klein: The Need for an Entrepreneurial Theory of the Firm.

2008-5 Nicolai J. Foss \& Peter G. Klein: Entrepreneurship: From Opportunity Discovery to Judgment.

2008-6 Mie Harder: How do Rewards and Management Styles Influence the Motivation to Share Knowledge?

2008-7 Bent Petersen, Lawrence S. Welch \& Gabriel R.G. Benito: Managing the Internalisation Process - A Theoretical Perspective.

2008-8 Torben Juul Andersen: Multinational Performance and Risk Management Effects: Capital Structure Contingencies. 
2008-9 Bo Bernard Nielsen: Strategic Fit and the Role of Contractual and Procedural Governance in Alliances: A Dynamic Perspective.

2008-10 Line Gry Knudsen \& Bo Bernhard Nielsen: Collaborative Capability in R\&D Alliances: Exploring the Link between Organizational and Individual level Factors.

2008-11 Torben Juul Andersen \& Mahesh P. Joshi: Strategic Orientations of Internationalizing Firms: A Comparative Analysis of Firms Operating in Technology Intensive and Common Goods Industries.

2008-12 Dana Minbaeva: HRM Practices Affecting Extrinsic and Intrinsic Motivation of Knowledge Receivers and their Effect on Intra-MNC Knowledge Transfer.

2008-13 Steen E. Navrbjerg \& Dana Minbaeva: HRM and IR in Multinational Corporations: Uneasy Bedfellows?

2008-14 Kirsten Foss \& Nicolai J. Foss: Hayekian Knowledge Problems in Organizational Theory.

2008-15 Torben Juul Andersen: Multinational Performance Relationships and Industry Context. 